\title{
EVALUASI KETAHANAN GENOTIP PADI BERAS MERAH (Oryza sativa L.) TERHADAP PENYAKIT BLAS DAUN (PyriculariaoryzaeCav.) RAS 173
}

\author{
Putu ShantiawanPrabawa ${ }^{1}$, Damanhuri $^{2}$ \\ E-mail: putushantiawan@gmail.com \\ ${ }^{1}$ Staf edukatif Fakultas Pertanian Universitas Panji Sakti Singaraja, Bali \\ ${ }^{2}$ Staf edukatif Fakultas Pertanian Uiversitas Brawijaya, Malang
}

\begin{abstract}
Constraints in rice cultivation are attacks by pathogens such as fungus Pyricularia oryzae Cav. causes of blast disease. The use of varieties that are resistant to blast disease is an effective solution to increase production. This is because of the diverse race of blast disease that develops, one of the most virulent is race 173. To produce resistant rice varieties, a blast disease resistant gene is needed sourced from local genotypes of brown rice. This study aims to test the resistance of 5 local genotypes of brown rice, to know diversity and to predict whether these traits can be inherited. The study was conducted in February - May 2014, in Ketawang village, Gondanglegi sub-district, Malang district. The material used is 5 local genotypes of brown rice and 2 varieties of check. This research uses the design of IRRI SES. The results showed the Mandel genotype had the best appearance on all invulnerability characters such as latent periods, invulnerability scores and intensity of disease attacks.
\end{abstract}

Keywords: brown rice, blast disease, invulnerability

Abstrak: Kendala dalam budidaya tanaman padiadalah adanya serangan patogen seperti cendawan Pyricularia oryzae Cav. penyebab penyakit blas. Penggunaan varietas yang tahan penyakit blas adalah solusi yang efektif untuk meningkatkan produksi. Hal ini karena beragamnya ras penyakit blas yang berkembang, salah satunya yang paling virulen adalah ras 173 . Untuk menghasilkan varietas padi yang tahan, diperlukan gen tahan penyakit blas yang bersumber dari genotip lokal padi beras merah. Penelitian ini bertujuan untuk menguji ketahanan 5 genotip lokal padi beras merah, mengetahui keragaman dan menduga apakah sifat tersebut dapat diwariskan. Penelitian dilaksanakan pada bulan Februari - Mei 2014, di desa Ketawang, kecamatan Gondanglegi, kabupaten Malang. Bahan yang digunakan adalah 5 genotip lokal padi beras merah dan 2 varietas cek. Penelitian ini menggunakan rancangan IRRI SES. Hasil penelitian menunjukkan genotip Mandel memiliki penampilan terbaik pada semua karakter ketahanan seperti periode laten, skor tingkat ketahanan dan intensitas serangan penyakit.

Kata kunci : padi beras merah, penyakit blas, ketahanan

\section{PENDAHULUAN}

Padi (Oryza sativa L.) adalah tanaman serealia yang mengandung karbohidrat tinggi. Selain mengandung karbohidrat yang tinggi, pada padi beras merah juga terdapat kandungan gizi serta antioksidan yang tinggi (Gealyand Bryant, 2009). Namun, padi beras merah di Indonesia kurang mendapat perhatian. Kurangnya perhatian terhadap padi beras merah ini disebabkan oleh hasil produksi padi merah yang masih rendah (Aryana, 2009). Serangan penyakit menjadi salah satu penyebab rendahnya hasil produksi padi merah selain karena faktor genetik. Penyakit blas adalah penyakit penting pada tanaman padi yang disebabkan oleh cendawan Pyricularia oryzae Cav
(Santoso dan Nasution, 2012). Penurunan hasil padi merah akibat serangan penyakit blas dapat dicegah dengan menggunakan varietas tahan blas. Pengendalian penyakit blas dengan varietas tahan selain ramah lingkungan, biayanya juga murah.

Terdapat banyak varietas tahan nasional, namun sebagian besar hanya memiliki satu gen ketahanan penyakit blas, sehingga mudah untuk dipatahkan. Banyaknya ras penyakit blas yang berkembang juga menjadi penyebab ketahanan dari varietas tahan mudah dipatahkan. Santoso dan Nasution (2012) menyebutkan terdapat lebih dari 30 ras Pyricularia oryzae Cav. yang teridentifikasi dengan menggunakan varietas diferensial di Indonesia. Karena beragamnya ras dari Pyricularia oryzae 
Cav. perlu dilakukan evaluasi untuk mendapatkan sumber genetik yang tahan terhadap ras penyakit blas, salah satunya pada genotip lokal padi beras merah. Tujuan penelitian ini adalah untuk mengetahui tingkat ketahanan 5 genotip lokal padi beras merah yang kedepannya dapat digunakan sebagai sumber pemuliaan tanaman untuk menhasilkan varietas tahan penyakit blas.

\section{BAHAN DAN METODE}

Sebanyak 5 genotip lokal padi beras merah (Tabel 1) dari beberapa daerah di Bali dan Jawa diuji ketahanannya terhadap penyakit blas daun di daerah endemik penyakit blas yaitu di desa Ketawang, kecamatan Gondanglegi, Malang pada periode bulan Februari - Mei 2014, menggunakan rancangan SES IRRI. Varietas cek (pembanding) yang digunakan adalah Ciherang (cek rentan) dan INPAGO 7 (cek agak tahan). Metode pengujian menggunakan metode blast nursery yaitu metode inokulasi penyakit secara alami menggunakan tanaman spreader sebagai sumber inokulan dan penyebar penyakit. Sebagai spreader digunakan varietas Ciherang sekaligus cek rentan. Setiap genotip lokal yang diuji ditanam pada bedengan dengan ukuran 2 $\mathrm{m} \times 1 \mathrm{~m}$, pada bagian pinggir bedengan ditanami spreader dengan ketebalan \pm 15 $\mathrm{cm}$ dan ditanam lebih awal dibandingkan genotip yang diuji dan varietas ceknya. Tujuan ditanamnya spreader lebih awal adalah sebagai sumber inokulum penyakit blas bagi genotip yang diuji dan varietas ceknya. Jarak tanam antar genotip yang diuji dan varietas cek adalah $5 \mathrm{~cm}-10 \mathrm{~cm}$. Jarak tanam yang cukup dekat bertujuan untuk mempermudah penyebaran penyakit.
Pertanaman dipupuk dengan Urea $\left(\begin{array}{llll}45 \% & \mathrm{~N}\end{array}\right), \quad \mathrm{SP}-36\left(36 \% \mathrm{P}_{2} \mathrm{O}_{5}\right)$ dan $\mathrm{KCl}$ $\left(60 \% \mathrm{~K}_{2} \mathrm{O}\right)$. Pengamatan dilakukan pada umur tanaman 9 hst pada karakter periode laten, dan pada umur 30 hst, 37 hst, 44 hst, 51 hst dan 58 hst untuk karakter tingkat ketahanan dan intensitas serangan penyakit. Pengamatan karakter tingkat ketahanan genotip menggunakan skoring berdasarkan Standart Evaluation System For Rice (SES IRRI) (Tabel 2).

\section{HASIL DAN PEMBAHASAN}

Penelitian padi beras merah belum menjadi program utama pemuliaan tanaman di Indonesia, namun padi beras merah memiliki manfaat, prospek dan potensi yang tinggi sehingga sangat perlu untuk mendapat perhatian. Usaha pemuliaan untuk menghasilkan varietas yang tahan terhadap penyakit blas daun hanya dapat dilakukan apabila tersedia keragaman genetik yang tinggi. Suatu varietas bisa disebut unggul tidak hanya dilihat dari daya hasil yang tinggi, tetapi juga dari tingkat ketahanannya terhadap penyakit seperti penyakit blas. Tingkat ketahanan suatu tanaman padi terhadap serangan penyakit, khususnya penyakit blas tidak dapat ditentukan hanya dengan melihat dari satu karakter ketahanan saja, namun harus diamati secara menyeluruh. Dalam penelitian ini karakter yang digunakan sebagai indikator ketahanan suatu tanaman adalah periode laten, skor tingkat ketahanan dan intensitas serangan penyakit. Hal ini sesuai dengan karakter ketahanan penyakit blas yang diukur oleh Jusliah (2002).

Hasil pengujian menunjukkan bahwa dari lima (5) genotip lokal padi beras merah yang diuji terdapat dua (2) genotip yang menunjukkan tingkat ketahanan yang tinggi. Tiga (3) genotip lokal lainnya 
menunjukkan tingkat ketahanan yang moderat pada parameter pengamatan skoring tingkat ketahanan dan intensitas serangan penyakit. Pada parameter pengamatan periode laten genotip Slegreng menunjukkan periode laten yang paling lama yaitu 12 hari setelah tanam (hst), sedangkan 4 genotip lainnya menunjukkan periode laten yan sama yaitu $20 \mathrm{hst}$. Varietas cek sama-sama menunjukkan $\begin{array}{llll}\text { periode } & \text { laten } & 9 & \text { hst. }\end{array}$

Tabel 1 Genotip Lokal Padi Beras Merah dan Varietas Pembanding yang Digunakan

\begin{tabular}{c|l|l|l}
\hline No & \multicolumn{1}{|c|}{ Genotip Padi } & \multicolumn{1}{c|}{ Deskripsi } & \multicolumn{1}{c}{ Daerah Asal } \\
\hline 1 & INPAGO 7 & Varietas Cek Tahan & Varietas Nasional \\
\hline 2 & Ciherang & Varietas Cek Rentan & Varietas Nasional \\
\hline 3 & Cendana & Padi Beras Merah Lokal & Bali \\
\hline 4 & Slegreng & Padi Beras Merah Lokal & Yogyakarta, Jawa Tengah \\
\hline 5 & Mandel & Padi Beras Merah Lokal & Yogyakarta, Jawa Tengah \\
\hline 6 & L. Malang & Padi Beras Merah Lokal & Malang, Jawa Timur \\
\hline 7 & L. Temanggung & Padi Beras Merah Lokal & Temanggung, Jawa Tengah \\
\hline
\end{tabular}

Tabel 2 Skor Tingkat Ketahanan dan Klasifikasi Ketahanan Tanaman Padi akibat Serangan Penyakit Blas (Pyricularia oryzae Cav.)

\begin{tabular}{c|l|l}
\hline Skor & \multicolumn{1}{|c}{ Kerusakan Daun } & \multicolumn{1}{|c}{ Klasifikasi } \\
\hline 0 & Tidak ada gejala serangan & Sangat Tahan \\
\hline 1 & Bercak sebesar ujung jarum & Sangat Tahan \\
\hline 2 & Bercak lebih besar dari ujung jarum & Tahan \\
\hline 3 & $\begin{array}{l}\text { Bercak nekrotik, abu-abu, bundar, sedikit memanjang, panjang 1-2 mm, } \\
\text { tepi coklat }\end{array}$ & Agak Tahan \\
\hline 4 & $\begin{array}{l}\text { Bercak khas blas (belah ketupat) panjang 1-2 mm luas daun terserang } \\
\text { kurang dari 2\% }\end{array}$ & Moderat \\
\hline 5 & Bercak khas blas, luas daun terserang 2-10\% & Moderat \\
\hline 6 & Bercak khas blas, luas daun terserang 11-25\% & Agak Rentan \\
\hline 7 & Bercak khas blas, luas daun terserang 26-50\% & Rentan \\
\hline 8 & Bercak khas blas, luas daun terserang 51-75\%, beberapa daun mulai mati & Sangat Rentan \\
\hline 9 & Semua daun mati & Sangat Rentan \\
\hline
\end{tabular}

Periode laten adalah waktu yang dibutuhkan oleh patogen untuk menimbulkan gejala serangan pertama kali pada tanaman inang. Berdasarkan Gambar 1, Inpago 7 dan Ciherang sebagai tanaman cek sama-sama menunjukkan periode laten yang lebih cepat dibandingkan genotip yang diuji. Hal ini bisa menjadi indikator bahwa kedua varietas cek memiliki tingkat ketahanan yang rendah terhadap penyakit blas Ras 173. Menurut Tandiabang dan Syahrir (2007) semakin cepat periode laten, diindikasikan tanaman tersebut lebih rentan terhadap serangan penyakit.

Tingkat ketahanan suatu tanaman tidak bisa dinilai hanya dari satu parameter saja, melainkan perlu dilakukan perbandingan pada parameter lainnya. Tingkat ketahanan dari 5 genotip lokal padi beras merah dan varietas cek ditampilkan pada Tabel 3 yang dinilai berdasarkan parameter skor tingkat ketahanan dan intensitas serangan penyakit. 


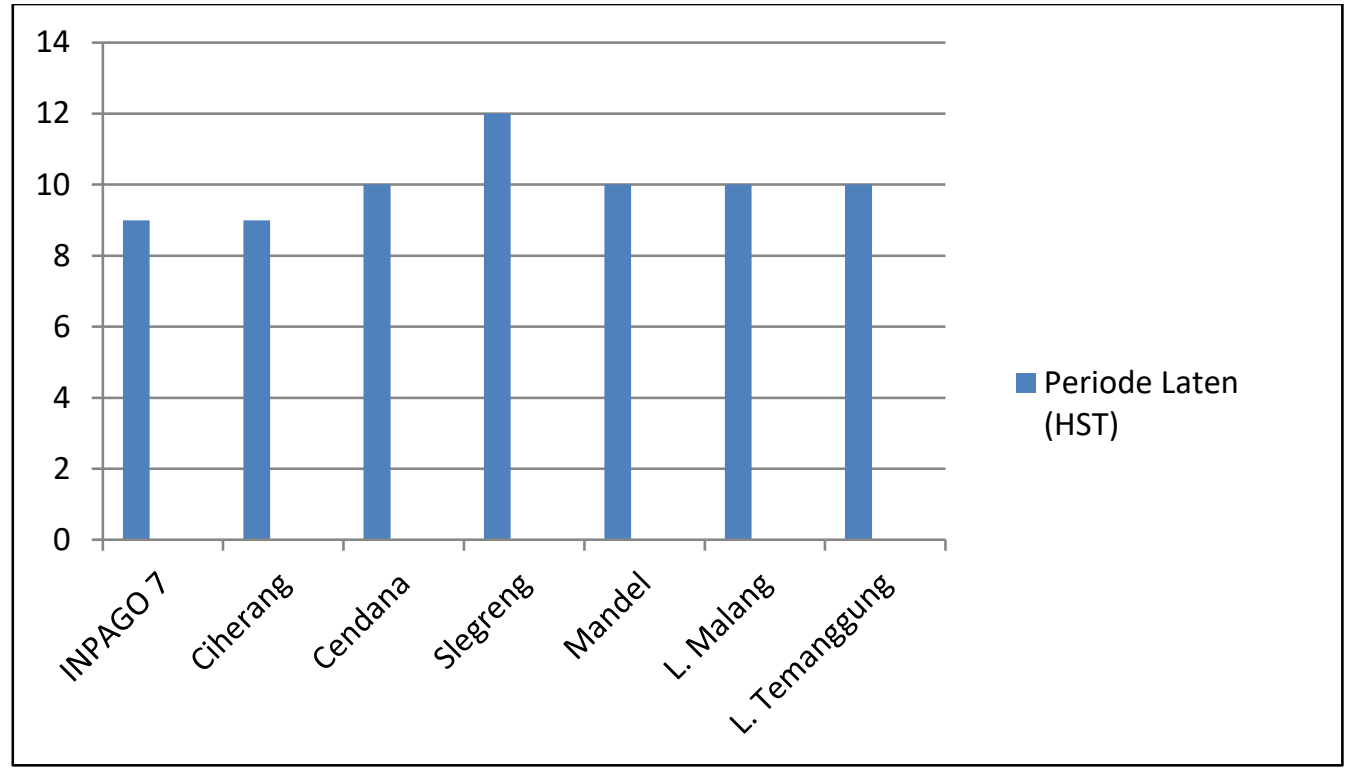

Gambar 1. Grafik Periode Laten Genotip Padi Beras Merah dan 2 Varietas Cek

Tabel 3. Matrik Ketahanan Padi Merah (Oryza sativa L.) Pada Penyakit Blas Daun (Pyricularia oryzae Cav.) Ras 173

\begin{tabular}{|c|c|c|c|c|c|c|c|c|c|c|}
\hline \multirow{2}{*}{ Genotip } & \multicolumn{5}{|c|}{ Skor Tingkat Ketahanan } & \multicolumn{5}{|c|}{ Intensitas Serangan Penyakit (\%) } \\
\hline & M4 & M5 & M6 & M7 & Rerata & M4 & M5 & M6 & M7 & Rerata \\
\hline IPG7 & $6,5 \mathrm{R}$ & $6,4 \mathrm{R}$ & $6,4 \mathrm{R}$ & $6,2 \mathrm{R}$ & $6,4 \mathrm{R}$ & $72,4 \mathrm{R}$ & $70,9 \mathrm{R}$ & $71,6 \mathrm{R}$ & $68,8 \mathrm{R}$ & $70,9 \mathrm{R}$ \\
\hline CHER & $7,1 \mathrm{R}$ & $7,0 \mathrm{R}$ & $7,1 \mathrm{R}$ & $7,2 \mathrm{R}$ & $7,1 \mathrm{R}$ & $80,0 \mathrm{R}$ & $77,7 \mathrm{R}$ & $78,9 \mathrm{R}$ & $79,1 \mathrm{R}$ & $78,9 \mathrm{R}$ \\
\hline CNDA & $2,1 \mathrm{~T}$ & $2,0 \mathrm{~T}$ & $2,0 \mathrm{~T}$ & $2,1 \mathrm{~T}$ & $2,1 \mathrm{~T}$ & $23,5 \mathrm{~T}$ & $22,2 \mathrm{~T}$ & $22,6 \mathrm{~T}$ & $23,1 \mathrm{~T}$ & $22,8 \mathrm{~T}$ \\
\hline SLGR & $3,8 \mathrm{M}$ & $3,2 \mathrm{M}$ & $3,1 \mathrm{M}$ & $2,8 \mathrm{M}$ & $3,2 \mathrm{M}$ & $27,5 \mathrm{R}$ & $36,0 \mathrm{R}$ & $33,7 \mathrm{R}$ & $31,4 \mathrm{R}$ & $32,5 \mathrm{M}$ \\
\hline MNDL & $2,1 \mathrm{~T}$ & $2,0 \mathrm{~T}$ & $2,0 \mathrm{~T}$ & $1,9 \mathrm{~T}$ & $2,0 \mathrm{~T}$ & $23,4 \mathrm{~T}$ & $22,2 \mathrm{~T}$ & $22,2 \mathrm{~T}$ & $21,7 \mathrm{~T}$ & $22,4 \mathrm{~T}$ \\
\hline LMLG & $3,9 \mathrm{M}$ & $3,7 \mathrm{M}$ & $3,1 \mathrm{M}$ & $2,8 \mathrm{M}$ & $3,4 \mathrm{M}$ & $43,3 \mathrm{R}$ & $40,7 \mathrm{R}$ & $34,1 \mathrm{R}$ & $31,3 \mathrm{R}$ & $37,4 \mathrm{M}$ \\
\hline LTMG & $4,1 \mathrm{M}$ & 3,7 M & $3,4 \mathrm{M}$ & $3,1 \mathrm{M}$ & $3,6 \mathrm{M}$ & $45,3 \mathrm{R}$ & $39,3 \mathrm{R}$ & $35,6 \mathrm{R}$ & $34,2 \mathrm{R}$ & $38,6 \mathrm{M}$ \\
\hline
\end{tabular}

Keterangan: IPG7 (Inpago 7), CHER (Ciherang), CNDA (Cendana), SLGR (Slegreng), MNDL (Mandel), LMLG (Lokal Malang), LTMG (Lokal Temanggung), M4-M7 (Minggu 4-7), T (Tahan), R (Rentan), M (Moderat). Huruf dan angka yang bercetak tebal adalah genotip yang memiliki tingkat ketahanan paling baik.

Hasil pengujiaan pada parameter skor tingkat ketahanan dan intensitas serangan penyakit menunjukkan Ciherang (cek rentan) dan Inpago 7 (cek agak tahan) menunjukkan serta skor tingkat ketahanan dan intensitas serangan penyakit yang tinggi sehingga di klasifikasikan sebagai genotip yang rentan. Kondisi pada Inpago 7 sebagai cek tahan namun menunjukkan reaksi yang rentan dapat disebabkan karena beberapa faktor seperti lebih virulennya ras cendawan $P$ oryzae yang menyerang pada lokasi penelitian atau karena sifat ketahanan yang dimiliki Inpago 7 termasuk sifat ketahanan vertikal (monogenik). Hal ini sesuai dengan yang disebutkan oleh Jusliah (2002) yang menyatakan bahwa ketahanan vertikal (monogenik) lebih mudah untuk diperoleh, namun lebih mudah juga dipatahkan ketahanannya.

Pengamatan parameter ketahanan pada 5 genotip padi beras merah menghasilkan dua genotip yang memiliki 
semua karakter yang diinginkan. Genotip yang tersebut adalah Cendana dan Mandel yang masing-masing memiliki periode laten yang cukup lama (10 hst), skor tingkat ketahanan masing-masing 2,1 dan 2,0 serta intensitas penyakit yang juga rendah yaitu 22,8 pada genotip Cendana dan 22,4 pada genotip Mandel. Dipilihnya kedua genotip tersebut berdasarkan dari pernyataan Wang et al., (1989) bahwa ketahanan dilapangan ditunjukkan dari berkurangnya jumlah bercak, periode laten lebih lama dan tingkat sporulasi yang lebih rendah. Hasil pengamatan pada tiga genotip padi beras merah lainnya menunjukkan tingkat ketahanan yang moderat. Menurut Mukelar dan Edwina (1987) perbedaan reaksi dari masingmasing tanaman disebabkan oleh perbedaan gen pengendali ketahanan tanaman terhadap ras patogen dan tingkat patogenitas dari ras Pyricularia yang berbeda. Genotip Slegreng, Lokal Malang, dan Lokal Temanggung meskipun menunjukkan reaksi ketahanan yang moderat namun juga masih dapat digunakan sebagai sumber pemuliaan tanaman, karena pada genotip yang menunjukkan reaksi yang moderat sistem pertahanannya masih aktif untuk menghadap penyebaran cendawan $P$ oryzae. Menurut Jusliah (2002) tanaman padi yang tahan dan agak tahan memiliki sistem pertahanan mekanis yaitu adanya endapan kersik (silium) pada dinding sel epidermisnya sehingga menyulitkan terjadinya infeksi karena hifa cendawan sulit melakukan penetrasi, yang menyebabkan tidak timbulnya gejala serangan berupa bercak pada daun tanaman padi.

\section{KESIMPULAN}

Pada 5 genotip lokal padai beras merah yang diuji terdapat 2 genotip menunjukkan reaksi tahan dan 3 genotip menunjukkan reaksi moderat. Kedau genotip tersebut adalah Cendana dengan periode laten 10 hst, skor tingkat ketahanan 2,1 dan intensitas serangan penyakit 22,8\%, dan genotip Mandel dengan periode laten $10 \mathrm{hst}$, skor tingkat ketahanan 2 dan intensitas serangan 22,4\%. Genotip Cendana dan Mandel dapat digunakan sebagai sumber pemuliaan untuk menghasilkan tanaman/varietas padi beras merah yang tahan terhadap penyakit blas dengan ras cendawan P.oryzae Cav. 173.

\section{DAFTAR PUSTAKA}

Aryana, M.I.G.P. 2009. Adaptasi dan Stabilitas Hasil Galur-Galur Padi merah Pada Tiga Lingkungan Tumbuh. Jurnal Agronomi. Indonesia 37 (2) : 95 - 100.

Bonman,

J.M. 1992.DurableResistancetoRiceBlas tDisease-EnvironmentalInfluence. Euphytica 63:115-123.

Gealy, D. R. and R. J. Bryant. 2009. Seed PhysicochemicalCharacteristicsOff ield-GrownUsWeedy Red Rice (Oryza sativaL.) Biotypes: ContrastsWith Commercial Cultivars. Journal of Cereal Science. 49: 239-245.

IRRI. 2006.StressandDiseaseTolerance: Breeding for diseaseResistanceinRice:Blast. http://www.knowledgebank.irri.org / ricebreedingcourse/ Breeding_for_disease_resistance_B last.htm (online). Diakses 8 Desember 2013

Jusliah. 2002. Uji Ketahanan 18 Genotipe Padi Gogo (OryzaSativa L.) Terhadap Dua Ras Penyakit Blas Daun (PyriculariaOryzaeCav). Jurusan Budidaya Pertanian. 
Fakultas Pertanian. Institut Pertanian Bogor.

Marquez-Ortiz, J.J., J.F.S. Lamb, L.D. Jhonson, D.K. Barnes, andR.E. Stucker. 1999.Heritability Of CrownTraits Internasional Alfalfa. CropScience. 39 :38-43.

Mukelar dan R. Edwina. 1987. Identifikasi ras jamur Pyricularia oryzae Cav. dari beberapa daerah di Indonesia. Kongres Nasional IX Perhimpunan
Fitopatologi Indonesia. 209-212 hal.

Santoso dan Nasution, A. 2012. Pengendalian Penyakit Blas dan Penyakit Cendawan Lainnya. Balai Besar Penelitian Tanaman Padi. Jawa Barat.

Wang, Z., D.J. Mackilland, J.MBonman. 1989.PartialResistancetoBlastinIndic aRice. CropScience. 29: 848-853. 